US Army Corps of Engineers ${ }_{\circledast}$

Engineer Research and

Development Center

\title{
Erosion Control of Earth Covered Magazines to Maintain Minimum Cover Requirements
}

Jameson D. Shannon

September 2019
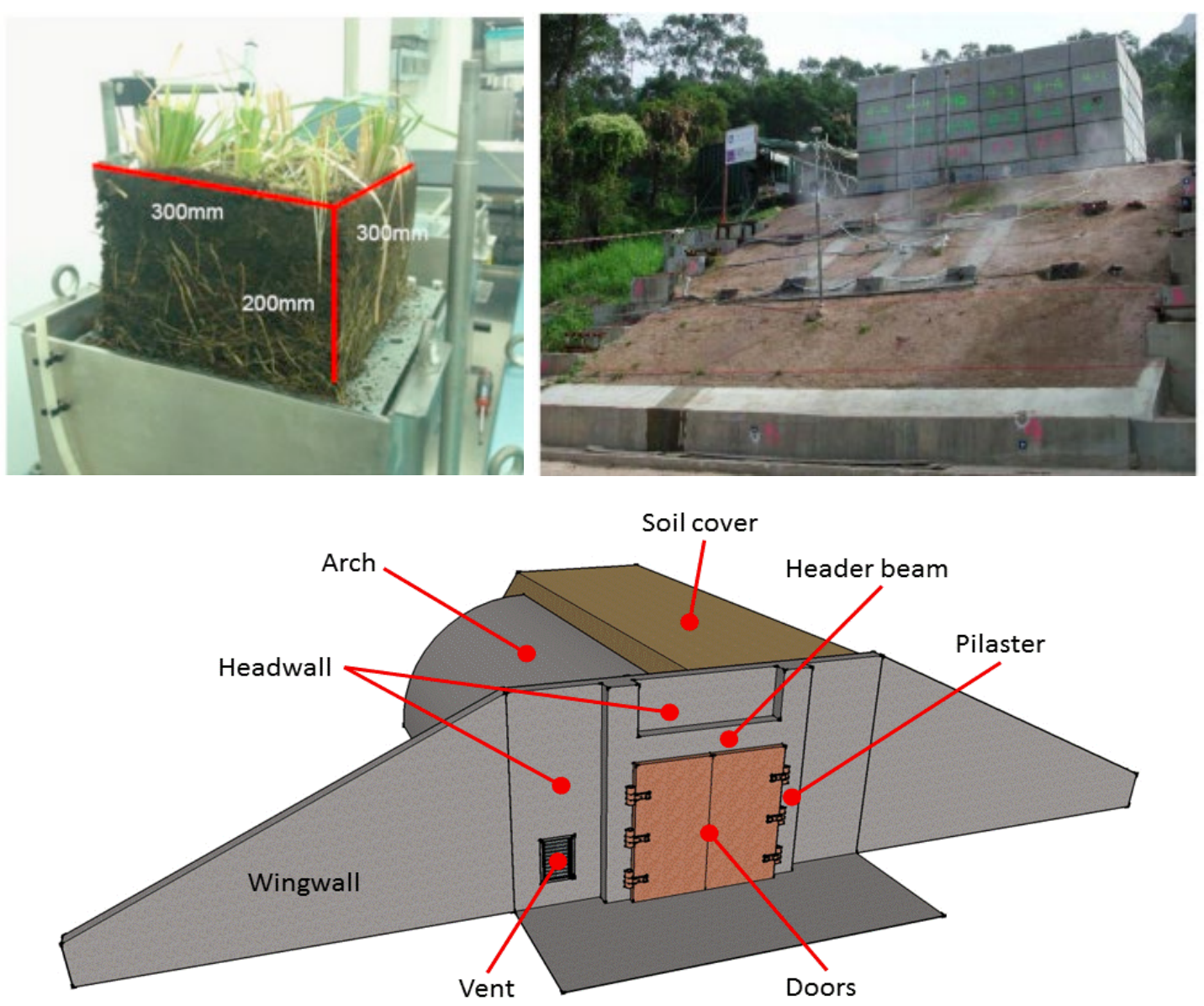

Approved for public release; distribution is unlimited. 
The U.S. Army Engineer Research and Development Center (ERDC) solves the nation's toughest engineering and environmental challenges. ERDC develops innovative solutions in civil and military engineering, geospatial sciences, water resources, and environmental sciences for the Army, the Department of Defense, civilian agencies, and our nation's public good. Find out more at www.erdc.usace.army.mil.

To search for other technical reports published by ERDC, visit the ERDC online library at http://acwc.sdp.sirsi.net/client/default. 


\title{
Erosion Control of Earth Covered Magazines to Maintain Minimum Cover Requirements
}

\author{
Jameson D. Shannon \\ Geotechnical and Structures Laboratory \\ U.S. Army Engineer Research and Development Center \\ 3909 Halls Ferry Road \\ Vicksburg, MS 39180-6199
}

Final report

Approved for public release; distribution is unlimited.

Prepared for U.S. Army Engineering and Support Center

Huntsville, AL 35816-5319

Under Project 479377, “ERDC Funds for Earth Cover Erosion” 


\section{Abstract}

Soil erosion of cover for earth covered magazine (ECM) storage presents a unique challenge to traditional embankment practices. Due to the strict guidelines on the necessary soil cover, as well as material allowed for use in erosion deterrence, many traditional soil erosion techniques are not allowable. This report investigates current soil erosion techniques and their applicability to magazine cover focusing on regulations, costs, and ease of implementation. The techniques investigated were based on currently used techniques from 2003 to the present but did not include researchonly stage mechanisms.

The objective of this research effort was to investigate currently available erosion mitigation methods and their feasibility for ECM application. Main areas of concern for ECMs are envisioned to be cost, ease of implementation, and potential for added debris.

Based on the reviewed literature, it appears that chemical or vegetative stabilization are likely the best methods for ECMs' erosion prevention. This assumes that simple soil compaction is not adequate, as it is otherwise generally the best approach. After a selection is made of a proposed solution to this issue, additional testing is suggested as a proof of erosion deterrence.

DISCLAIMER: The contents of this report are not to be used for advertising, publication, or promotional purposes. Citation of trade names does not constitute an official endorsement or approval of the use of such commercial products. All product names and trademarks cited are the property of their respective owners. The findings of this report are not to be construed as an official Department of the Army position unless so designated by other authorized documents. 


\section{Contents}

Abstract.................................................................................................................................. if

Figures and Tables................................................................................................................

Preface ................................................................................................................

Unit Conversion Factors.................................................................................................... vi

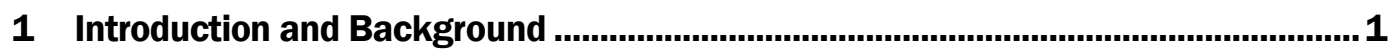

1.1 Earth covered magazine background and specifications ...........................

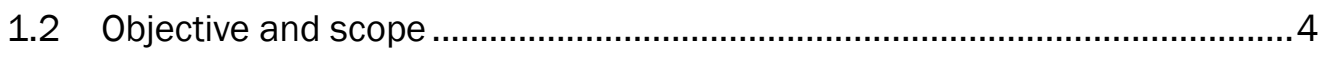

2 Erosion Control Methodologies............................................................................... 5

2.1 Mechanical stabilization .................................................................. 7

2.2 Vegetation based stabilization............................................................... 15

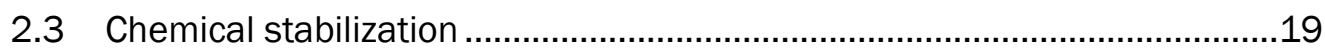

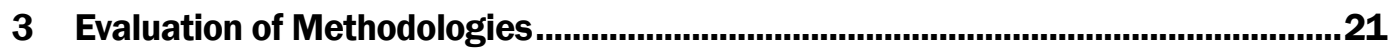

3.1 Optimum methodologies for use in ECMs............................................21

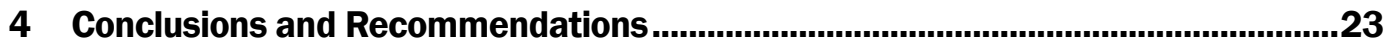

4.1 Conclusions....................................................................................... 23

4.2 Recommendations for additional study ......................................... 23

References.....................................................................................................................24

Appendix A: Additional Reference Material .........................................................31

Report Documentation Page 


\section{Figures and Tables}

\section{Figures}

Figure 1. ECM components and blast resisting elements (UFC 4-420-01)........................

Figure 2. Typical embankment style failure (Koerner 2015). ............................................. 6

Figure 3. Platepile installation (McCormick 2014)............................................................

Figure 4. Loose fill slope testing with soil nails (Li et al. 2008)...........................................10

Figure 5. Schematic of RPP section (Khan et al. 2017)...................................................11

Figure 6. Application of RPPs (Khan et al. 2017) ..........................................................12

Figure 7. Theoretical probability versus experimental findings for fiber blending (Kumar and Das 2018).

Figure 8. Hybrid soil nailing - geosynthetic system (Li et al. 2011)...................................14

Figure 9. Typical EPS block application (Arellano et al. 2011). ............................................15

Figure 10. Vetiver grass sample (Koerner 2015)................................................................16

Figure 11. Live pole stabilization (Wu et al. 2008). ..........................................................18

\section{Tables}

Table 1. Summary results of compressive creep tests on RPPs (Chen et al. 2017).........12

Table 2. Vetiver grass centrifuge testing results (8).......................................................... 17

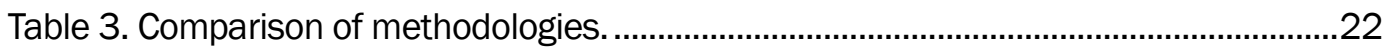




\section{Preface}

This project was conducted for the U.S. Army Engineering and Support Center in Huntsville, AL, under Project Number 479377, "ERDC Funds for Earth Cover Erosion".

This work was performed by the Concrete and Materials Branch (GMC), Engineering Systems and Materials Division (GM), U.S. Army Engineer Research and Development Center, Geotechnical and Structures Laboratory (ERDC-GSL). At the time of publication, Christopher M. Moore was Chief, CEERD-GMC; Justin S. Strickler was Chief, CEERD-GM; and Pamela G. Kinnebrew, CEERD-GZT, was the Technical Director for Military Engineering. The Deputy Director of ERDC-GSL was Charles W. Ertle, and the Director was Bartley P. Durst.

The Commander of ERDC was COL Teresa A. Schlosser and the Director was Dr. David W. Pittman. 


\section{Unit Conversion Factors}

\begin{tabular}{|l|c|l|}
\hline Multiply & By & To Obtain \\
\hline cubic feet & 0.02831685 & cubic meters \\
\hline degrees Fahrenheit & $(\mathrm{F}-32) / 1.8$ & degrees Celsius \\
\hline feet & 0.3048 & meters \\
\hline gallons (US liquid) & $3.785412 \mathrm{E}-03$ & cubic meters \\
\hline inches & 0.0254 & meters \\
\hline square feet & 0.09290304 & square meters \\
\hline square inches & $6.4516 \mathrm{E}-04$ & square meters \\
\hline yards & 0.9144 & meters \\
\hline
\end{tabular}




\section{Introduction}

\subsection{Earth covered magazine background and specifications}

The Unified Facilities Criteria (UFC) 4-420-01 Ammunition and Explosives Storage Magazines specification serves as a reference tool to assist in the planning, siting, and design of Ammunition and Explosives (AE) storage magazines for the Department of Defense (DoD) (UFC 4-420-01). The UFC applies to all services and DoD contractors. It is intended to assist in the selection of an $\mathrm{AE}$ storage magazine that was previously approved by the Department of Defense Explosives Safety Board (DDESB). DDESB approved protective construction and explosives safety criteria can be found in DDESB Technical Paper 15, Approved Protective Construction. Servicespecific safety standards that implement DoD standards are also available (DoD 4145.26-M, AFMAN 91-201, AR 385-10, NAVSEA OP 5 Volume 1). In the event of conflict in specifications between the UFC documents and the service-specific and DDESB requirements, the latter governs.

According to the DDESB, storage magazines can be classified as either Aboveground Magazines (AGMs or Earth Covered Magazines (ECMs). ECMs can be further classified as 7-Bar, 3-Bar, or Undefined. Classification is based mainly on the structural strength of the magazine headwall relative to the strength of the roof. The 7-Bar magazines provide a high level of blast resistance. These magazines may be referred to as "standard." The 3-Bar magazines provide a lower level of blast resistance, and Undefined ECMs provide an even lower level of blast resistance than 3-Bar. Undefined ECMs may be referred to as "non-standard." It should be noted that any ECM without a minimum of $2 \mathrm{ft}$ of cover is considered an AGM.

DoD explosives safety standards are contained in DoD 6055.09-M, DoD Ammunition and Explosives Safety Standards. The intended function of the ECM is to mitigate detonation of AE or adjacent ECMs, to resist external detonation, and to prevent the subsequent detonation of adjacent ECMs. The use of an approved standard design is required for magazine construction except in cases in which a preapproved design is not deemed suitable, but the magazine must still meet all requirements of DoD 6055.09-M. 
Minimum distances between a Potential Explosion Site (PES) and an Exposed Site (ES) are known as Quantity-Distances (QDs) and are based on multiple factors. Common factors include the level of protection required by the applicable standard, ES type, net explosive weight (NEW), hazard classification, physical orientation, and presence of other mitigation factors. The minimum safety QDs are based on maximum risk allowable and are listed in the specific explosives safety standards for each service (DoD 4145.26-M, AFMAN 91-201, AR 385-10, NAVSEA OP 5 Volume 1).

A 7-Bar (standard) ECM is generally permitted to be sited at a lower spacing and a storage capacity of 500,000 lbs NEW. An Undefined (non-standard) ECM is generally permitted at a higher spacing between magazines and a capacity of 250,000 lbs NEW. The 3-Bar magazines are generally specified at lower spacings than an Undefined and a capacity of 500,000 lbs NEW.

Typical ECMs are constructed with a semicircular arch or oval of reinforced concrete or steel, or as a "flat top" design as seen in Figure 1. The arch is not intended to mitigate internal explosions and is designed solely for supporting the structure. The base is generally a concrete floor slab, and in most cases, a reinforced concrete rear wall is present at the rear end. A reinforced concrete headwall that extends $2.5 \mathrm{ft}$ above the top of the structure is designed to mitigate adjacent blasts. Some designs may feature two headwalls instead of a headwall and rear wall. Reinforced concrete wing walls on each side of the headwall retain fill or cover slopes to meet ECM requirements. A minimum of $2 \mathrm{ft}$ of earth cover is required on the top, sides, and rear of the ECM. This requirement did not become standard until the early 1940s. A recent collection of ECM designs approved for new construction are listed in DDESB Technical Paper 15 in Table AP1-1, while the most current collection of approved designs, approval letters, and additional information can be accessed from the Whole Building Design Guide.

Maximum slopes for earth cover are 2:1, and constraints are placed on materials used. The material must be free of deleterious organic matter, trash, debris, stones heavier than 10 pounds, and stones larger than 6 in. Cobble sized stones, usually described as 2.5 in. or greater, are limited to lower and central portions of the earth cover, and clays are not permitted due to excessive cohesion. The material should be compacted to maintain integrity and erosion control. In locations where materials are not available to 
adequately maintain side slopes, it is permissible to use other materials or stabilization methods.

Figure 1. ECM components and blast resisting elements (UFC 4-420-01).
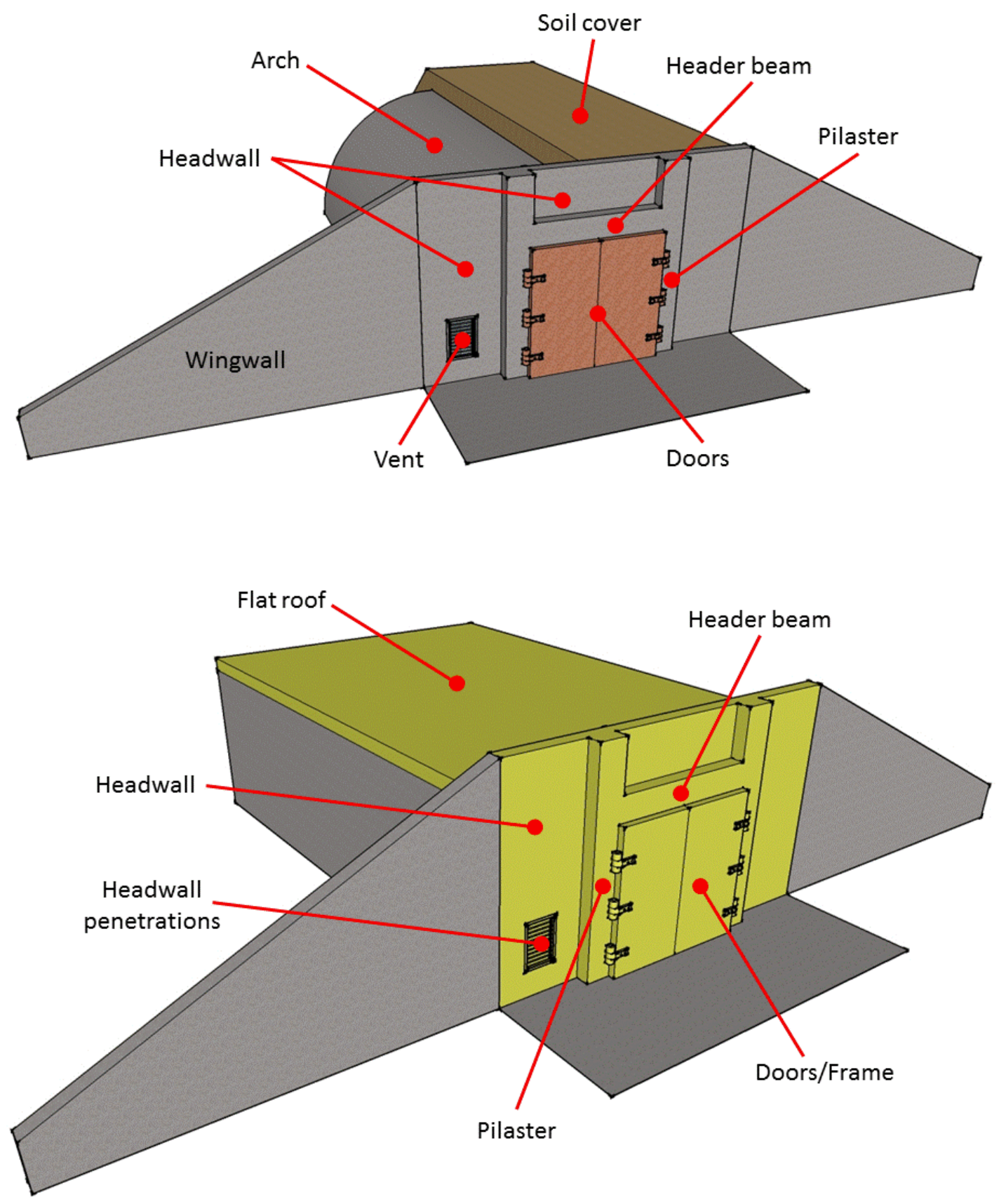


\subsection{Objective and scope}

The objective of this research effort is focused on investigating currently available erosion mitigation methods and their feasibility for ECM application. Main areas of concern for ECMs are envisioned to be cost, ease of implementation, and potential for added debris. The scope of technologies investigated was limited to techniques that have been used previously or are in a ready-to-use state. Technologies that are at the research-only level were not included. Specific examples of current projects are included, and only techniques featuring real use from 2003 to the present are discussed. The following chapter gives an overview of existing methods with potential for erosion control, and applicability of these methods to ECMs is discussed in section 3.1. 


\section{Erosion Control Methodologies}

ECMs earth cover could be classified as an embankment, i.e., soil fill brought in externally to create an artificial slope. While embankments are designed to maintain constructed slope, they are susceptible to changes in conditions, such as shrink-and-swell moisture changes that can change material properties and alter expected gradients. Therefore, while constructability and erosion control are integrated into the design of the embankment, future environmental factors should be considered in the choice of erosion control mechanisms.

In general, materials used for embankments or fills can be categorized as cohesive or cohensionless. Cohesive soils contain clay and silt materials that, when at the specified water content and density, are nearly impermeable. Pertinent properties of cohesive soils are not necessarily improved when compacted, and additional characterization is often required to determine the interaction of the material with the subgrade and determine the most optimum properties. Cohesionless materials are generally pervious materials such as sands, gravels, and cobbles. These materials are less impacted by water content changes and, when used as fill, are usually defined and placed by density requirements.

Soil characteristics can be substantially different even in relatively nearby environments, and certain slope stabilization techniques depend substantially on specific soil properties. Given the magnitude of ECMs and variations in locales, it is likely of greatest interest to avoid attempting to quantify a single best solution as this would only apply locally. Therefore, the approach taken investigated multiple options that could be used in several difference scenarios, while acknowledging that an acceptable stabilization technique that is widely implementable is likely of more use than specific local best practices.

The main form of erosion affecting ECM slopes is most likely due to precipitation (Eab et al. 2015). Erosion caused by water can occur in multiple forms of varying severity. Sheet erosion occurs when rain impacts bare soil resulting in a dislocation of soil particles, and the water then forms shallow channels on the surface carrying particles away. When the volume of water is large enough to form micro-channels up to 1.2-in. wide and 3-in. deep, this is known as rill erosion and can lead to the more severe gully erosion. In man-made sloped structures, there is increased risk of dry- 
ravel, the movement of particles down slope by gravity, which can also be exacerbated by wind especially in dry climates. Figure 2 illustrates this typical embankment style failure.

Figure 2. Typical embankment style failure (Koerner 2015).
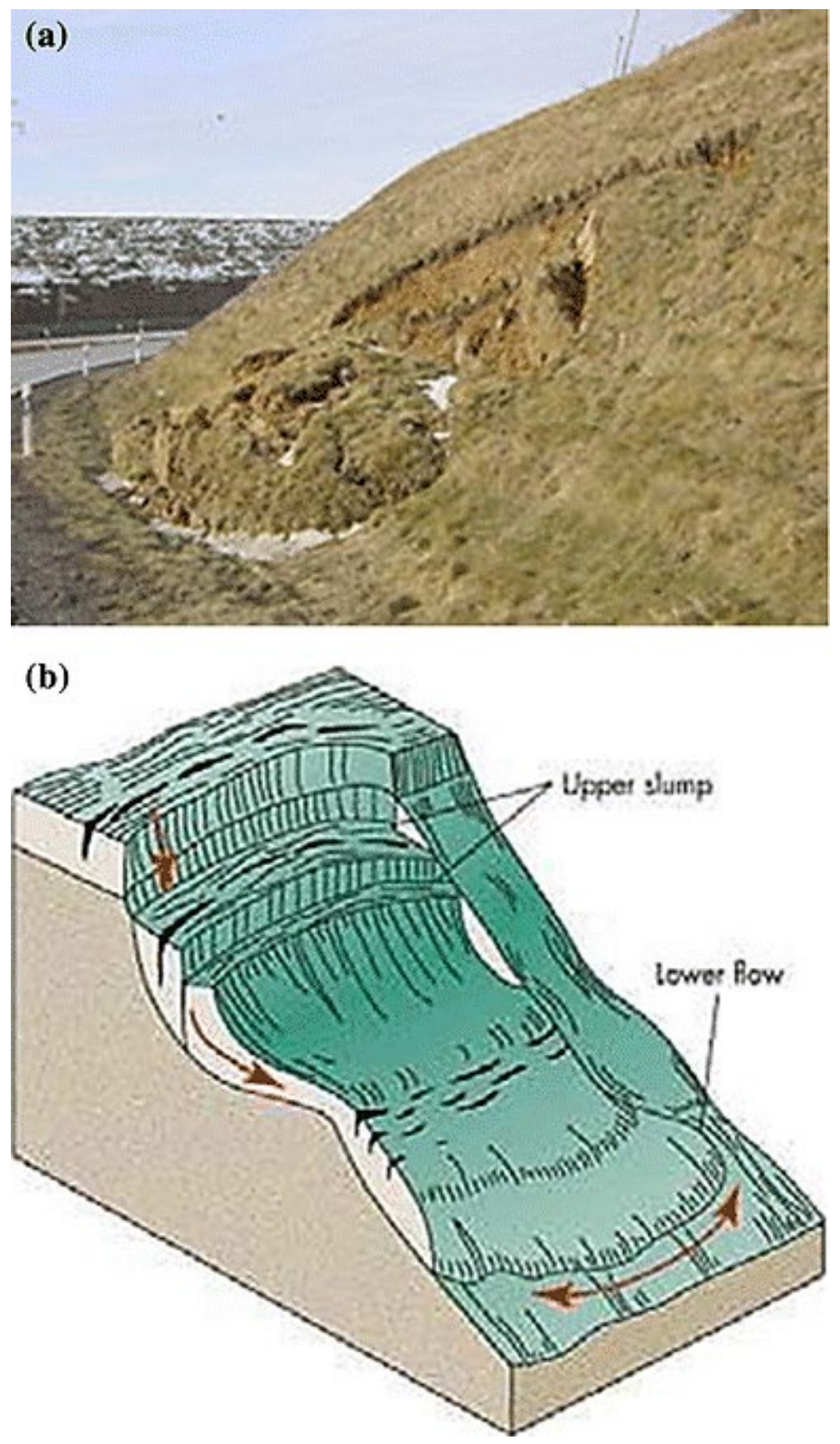

Generally accepted principles for erosion control are to reduce erosive forces, apply erosion control, modify grade, limit exposure, reduce runoff velocity, and maintain treatments. In the case of ECMs, reducing erosive 
forces, limiting exposure, modifying grade, and reducing runoff velocity are likely impractical due to the constraints of the ECM design and locations. Maintenance of treatments, considering the widespread use of ECMs, may also be prohibitively costly. The techniques described in this report will therefore be centered on the application of erosion control mechanisms with an emphasis on low maintenance, low cost, and overall effectiveness.

Erosion control techniques can be categorized into either physical control mechanisms such as the addition of piles, fabrics, textiles, vegetation, etc. to the slope or as chemical stabilization in which admixtures are mixed into the soil to alter soil properties. These changes are typically designed to increase shear strength, decrease permeability, control shrinking and swelling of soil, and in general, improve beneficial soil characteristics. Typical soil movement is most commonly due to lateral sliding forces, higher water levels, or a combination of both (Beck and Sharma 2013).

As in other engineering fields, erosion control efforts can be overly conservative leading to high costs (Hajiazizi and Mazaheri 2015). Additionally, in certain soil stabilization techniques such as chemical stabilizers, overly conservative engineering can actually lead to deficient stabilization. Care should be taken to specify only the appropriate level of stabilization required to promote efficient design and low costs. The following sections include detailed information and evaluations of various erosion control techniques.

\subsection{Mechanical stabilization}

The simplistic form of soil and embankment stabilization and likely the most cost efficient is typically the selection of appropriate materials and compaction densities. If the specific material properties are not available locally, it can be beneficial to import materials from offsite, although this may cause unwanted environmental impacts.

The mixing of multiple soils to achieve desired soil properties can be a feasible alternative when a single material is unavailable. Combining multiple locally sourced natural soils, it may be possible to produce a soil with greater erosion resistance than either soil separately. However, this type of stabilization would have to be evaluated on a case by case basis considering site and locally available materials. Even with a single local soil source, 
it may be possible to achieve desired performance properties through appropriate compaction and placement techniques.

Compaction to the appropriate density is generally perceived as one of the crucial factors in preventing erosion. Compaction can be achieved by common roller compacters or in some cases by standard excavators likely on site already to procure and place materials. Dynamic compaction, striking the soil with powered compacting tools, can also be used to achieve prescribed densities. For coarse-grained soils, densification via vibro-compaction or vibro-floatation, in which vibrating compacting tools are utilized, may provide additional compaction.

Since water is a primary factor in slope stabilization, it may be possible to alleviate some erosion concerns simply by installing traditional or novel drainage systems. Site characterization, groundwater movement, and horizontal drain implementation are well documented and can decrease slope creep (Pohll et al. 2013). Recycled concrete aggregates have also shown the capability to provide drainage when used in appropriate layers with fine aggregates (Rahardjo et al. 2013).

Typical soil movement is most commonly due to lateral sliding forces, higher water levels, or a combination of both (Beck and Sharma 2013), therefore traditionally common forms of stabilization include retaining walls, concrete facing, cover, layering, or compacted grouting to increase the performance properties of the affected soil. This can be conducted using conventional concrete and cementitious materials and is often the most effective, albeit expensive, form of stabilization (Thelen and Thorne 2013, Haghshenas et al. 2017). Thinner facings and layers than traditional concrete are also possible utilizing shotcrete applications. In this specific scenario of earth covered magazines, traditional concrete and shotcrete stabilization would likely be prohibitively expensive and could potentially create hazardous debris.

Concrete or steel piles/columns implemented in the embankment have been used successfully to mitigate shear forces. This technique may allow for the increase in beneficial properties at a reduced cost compared to concrete facing or layering. For example, drilled shafts filled with concrete have shown success in reducing the soil movement in multiple slope scenarios (Li and Liang 2014). Optimal locations of piles based on resistive and retaining forces have been established (Li et al. 2012). 
The California Department of Transportation developed a concept known as "platepile" in which mini-piles are placed in a staggered grid design (McCormick 2014). This system has been shown to reduce soil creep by 20-50\% in clays. Currently, the main use of this technology has been sloped embankments for roadways. Platepile installation is shown in Figure 3 .

Figure 3. Platepile installation (McCormick 2014).

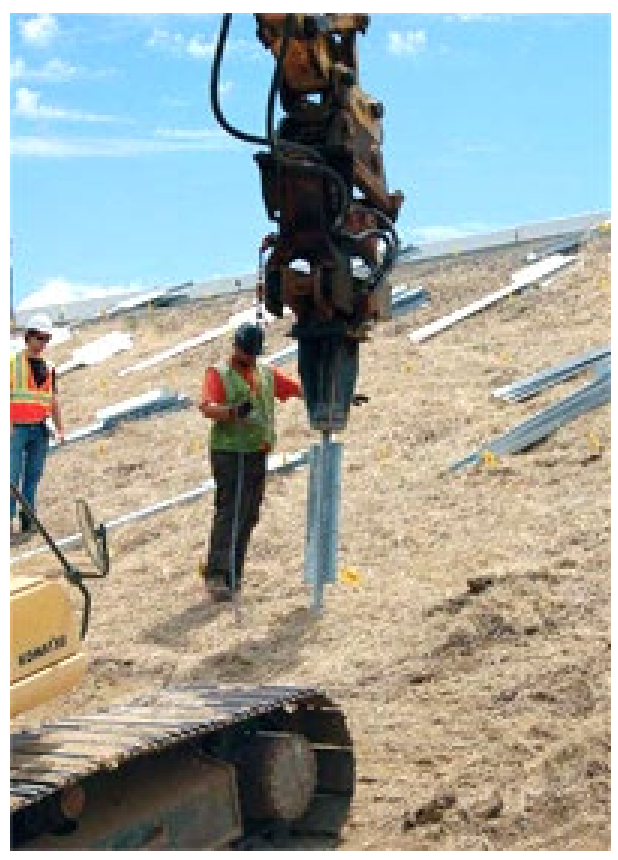

Various studies have been performed utilizing soil-structure interactions to evaluate optimal spacing and sizes of pile or column systems (Boeckmann 2006). Recycled concrete or rockfill may also be utilized to further decrease costs (Alfaro et al. 2009, Chen and Jia 2008, Mahmood et al. 2014). With these techniques, however, a large amount of testing, research, and material data are likely required to ensure that the piles/columns intersect the critical slip surfaces.

Grouted steel anchors, sometimes referred to as soil nails, have been used to control erosion by reducing shear slip forces in a similar methodology to piles/columns (Quansah et al. 2018). The anchors are driven into the soil slope at specified distances so that an equilibrium is achieved by soil on either side of the failure plane. Optimum installation angles based on failure planes can be calculated, and applications and software packages are available to determine critical nail positioning and depths to ensure soil stability (Ismail et al. 2018, Chen and Liu 2007). Various parameters such as 
grouting pressure, overburden pressure, soil dilation, degree of saturation, and roughness of the nail surface can all have an effect on the pullout capacity of the nail, a common critical parameter for design (Sharma et al. 2019a). Some studies indicate that the force used to drive the nail can be optimized to provide a shock wave to deform the soil and provide a bond to the nails (Smith et al. 2009).

Modified versions of soil nailing using bamboo or wood composites can alleviate cost concerns and provide increased sustainability, and recycled materials such as rail ties have also shown use in soil nailing and piling stabilization (Castro and Lopez 2006). Furthermore, during implementation, it is possible to add instrumentation, such as fiber optic monitoring systems, to the anchors in order to monitor soil properties and erosion control performance (Monsberger et al. 2018). Specifically in the context of this research effort, soil nailing has been evaluated for loose fill slopes, and results indicated that the technique is applicable even with surcharges (Li et al. 2008). The testing protocol for the loose fill slopes is shown in Figure 4. A combination of soil nailing and subsurface drainage mechanisms is described in Pun and Urciuoli (2008).

Figure 4. Loose fill slope testing with soil nails (Li et al. 2008).

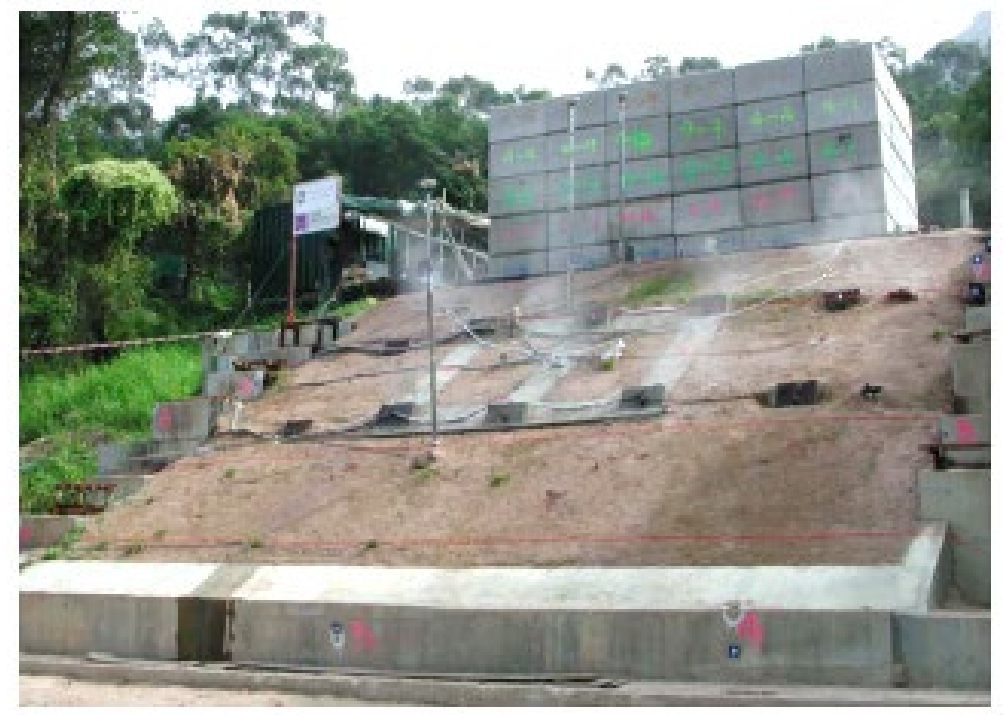

In some scenarios, concrete or natural piles, columns, or nails may be able to be replaced with polymers, foams, or similar materials and composites that can fulfill the same purpose without the added weight and debris hazard of concrete (Selvakumar and Soundara 2019). Recycled Plastic Pins (RPPs) manufactured from plastic waste can be used in similar ways as a 
soil nailing application (Khan et al. 2018). Typical waste materials include bottles, sawdust, and polymers (Khan et al. 2016). The material is lightweight and less susceptible to common degradation mechanisms. While this is still a newer, more unfamiliar design, multiple demonstration projects and case studies have shown significant success (Hussain 2017). The RPPs function in the same way as traditional soil nailing while providing cost and environmental advantages.

An embankment near Midlothian, Texas, utilized instrumented RPPs in 50 -ft sections. Results indicated less than $1.5 \mathrm{in}$. of slope deformation in the RPP sections and more than 15 in. of vertical settlement in control sections of the same size (Khan et al. 2017). Slopes were monitored over a five-year period. An illustration of the RPP sections is given in Figure 5 (schematic diagram) and Figure 6 (process and equipment). Additional case studies and design guides are also available (Bhuiyan 2014).

Figure 5. Schematic of RPP section (Khan et al. 2017).

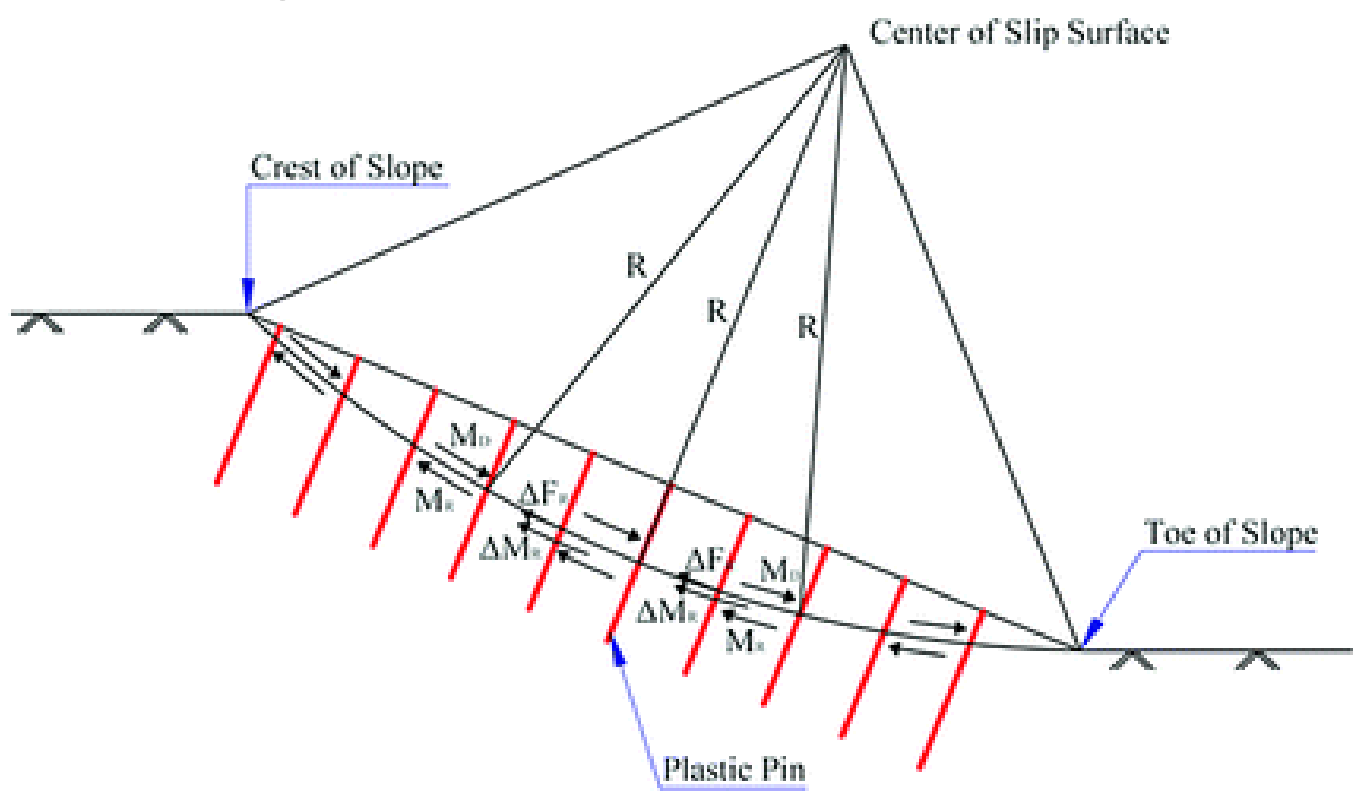


Figure 6. Application of RPPs (Khan et al. 2017).

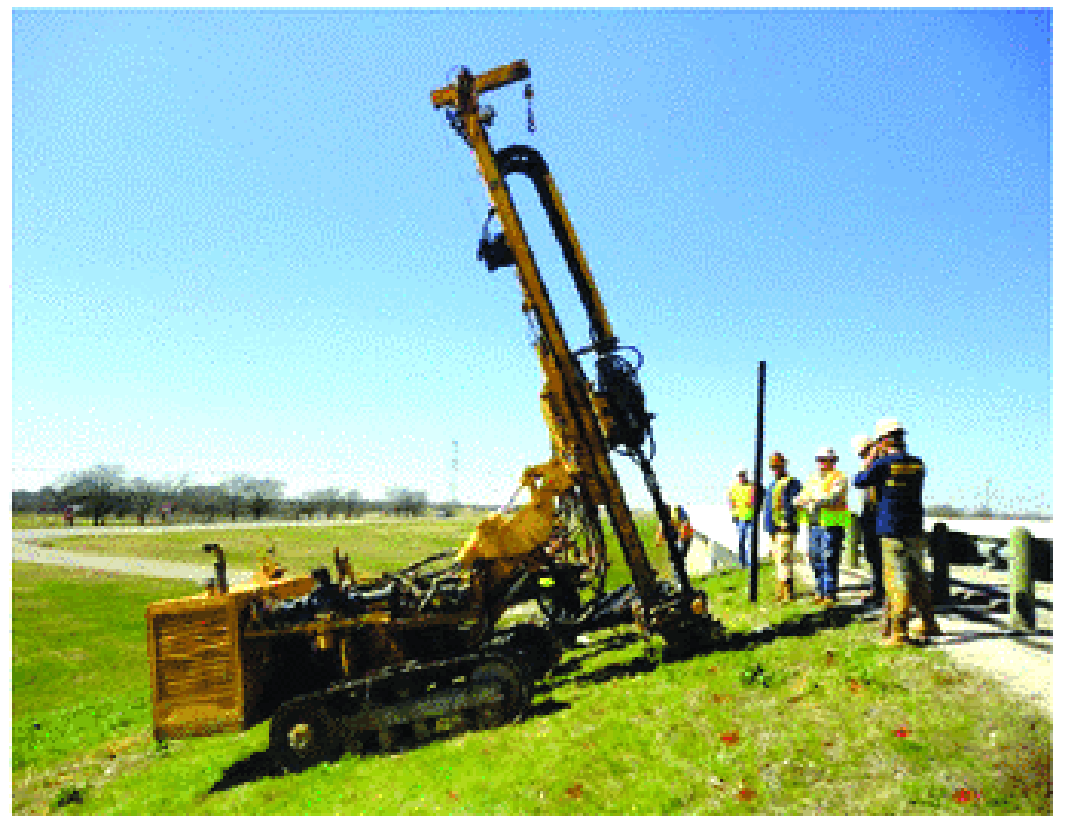

The properties of RPPs will vary with material and manufacturing process. However, it has been shown that, when utilizing the appropriate techniques, RPPs are capable of performance necessary to adequately support slopes. As an example, a selection of different RPP types and property data are shown in Table 1.

Table 1. Summary results of compressive creep tests on RPPs (Chen et al. 2017).

\begin{tabular}{|c|c|c|c|c|}
\hline Type & $\begin{array}{l}\text { Number of } \\
\text { specimens }\end{array}$ & $\begin{array}{l}\text { Creep stress } \\
\text { (kPa) }\end{array}$ & $\begin{array}{c}\text { Ratio of creep stress to } \\
\text { compressive strength }\end{array}$ & $\begin{array}{c}\text { Maximum } \\
\text { creep strain } \\
\text { (\%) }\end{array}$ \\
\hline A3 & 2 & 724 & 3.7 & 0.1 \\
\hline A6 & 2 & 690 & 6.3 & 0.1 \\
\hline B7 & 1 & 758 & 5.3 & 0.4 \\
\hline C9 & 1 & 827 & 5.1 & 0.4 \\
\hline
\end{tabular}

* Based on average compressive strength from uniaxial compression tests.

A potential negative impact of soil nailing or anchoring systems is the added debris on a PES location. RPP, bamboo, and wood alternatives may prove to alleviate any perceived issues with traditional steel or concrete anchors (Tardio et al. 2018). 
Fiber or geo-fiber stabilization includes the addition and mixing of small fibers, typically less than $100 \mathrm{~mm}$, to improve a material's erosion resistance. The addition of these fibers has been shown to reduce erosion forces and retain a larger amount of material than slopes with no erosion control treatment. Non-degrading fibers add to the effectiveness as treatments, and re-application of soil cover is not required. Other advantages include the ability to grow vegetation in addition to fibers and the ability to combine fibers with liquid or chemical stabilizers (Collins et al. 2015).

Geo-fiber stabilization is fundamentally dependent on the fiber properties. Attempts have been made to maximum potential benefits by stringently controlling these property parameters. For example, Himalayan nettle fibers infused with alkali treatments and lactic acid fibers cut to specific lengths and densities were blended to create nonwoven geotextiles meeting specific property requirements (Kumar and Das 2018). Processes similar to this can be used to manufacture the desired combination of cost and performance, although the process is likely more expensive than purchasing commercial fibers. Additionally, the effect of individual fiber properties on a final woven or nonwoven mesh is not clearly understood, as differences in individual properties and blending can substantially effect mesh properties. Figure 7 illustrates the possible differences between theoretical and realistic fiber blending.

Figure 7. Theoretical probability versus experimental findings for fiber blending (Kumar and Das 2018).

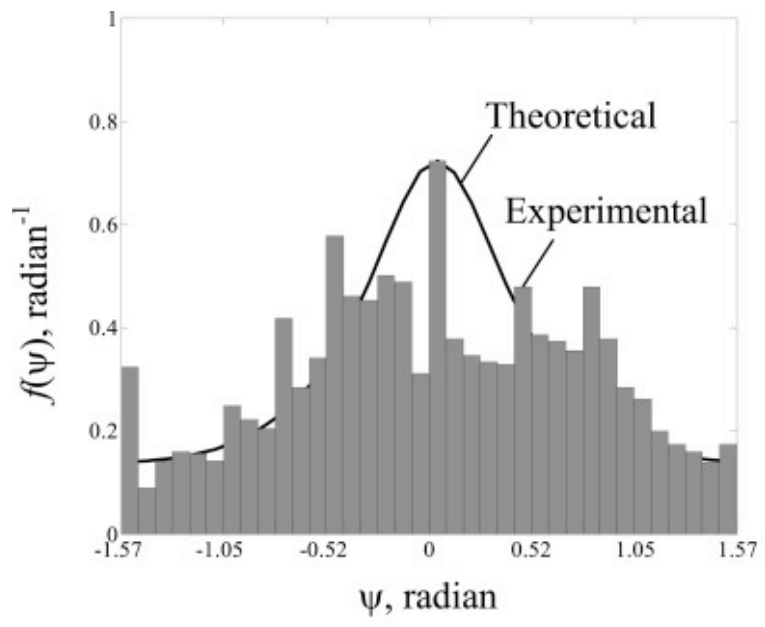

(a)

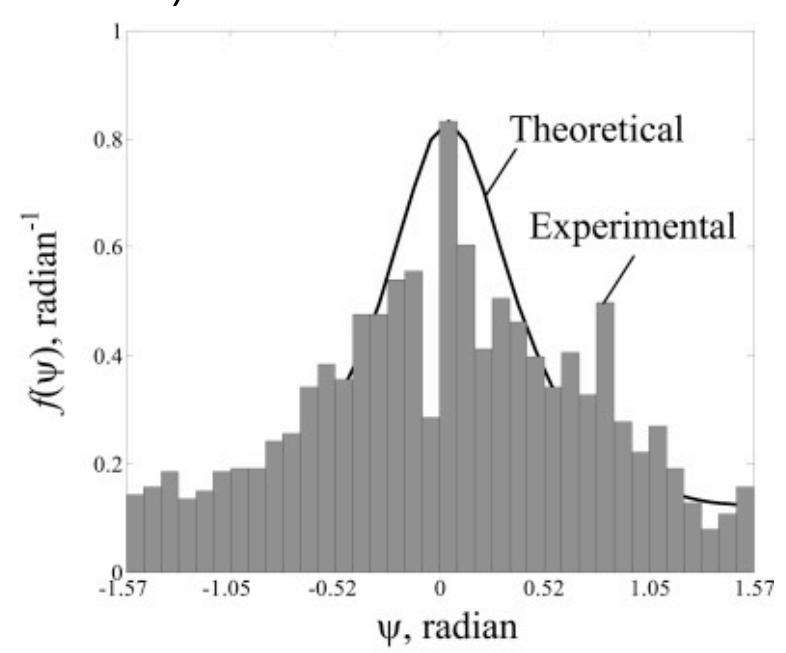

(b) 
Geosynthetic-Reinforced Soil (GRS) utilizes geosynthetic textile layering to increase soil shear strength and beneficial properties. This technique is often associated with simple design, relatively low cost, and ease of construction (Jotinsankasa and Rurgchaisri 2018). These textiles can be woven or non-woven and may be used with additional adhesives. The textiles can serve as a barrier to seepage or function as drainage layers to alleviate the erosion effect of precipitation. In addition to layering, geosynthetics can be utilized to form Geosynthetic Confined Soil (GCS) that may function similar to a retaining structure or supporting column (Turnbull 2017). A recent review of geosynthetic reinforced slopes including suitability, failure mode, analysis, design, and methodology was conducted by Shukla et al., 2011.

Geogrids (sometimes referred to as geocells) may be especially beneficial in cases with low cohesion and a high internal angle of friction (Sharma et al. 2019b). These materials can be used in multiple ways as a flexible load bearing or stabilization device, such as a geocell retaining wall (Li et al. 2011). Combinations of geomaterials such as textiles with nails, anchors, or chemical stabilizers is not uncommon. The system shown in Figure 8 illustrates a combination geosynthetic and soil nailing system that was successfully implemented in Upper Merion, PA. The system includes nails for shear support and an exterior layer of geosynthetic material.

Figure 8. Hybrid soil nailing - geosynthetic system (Li et al. 2011).
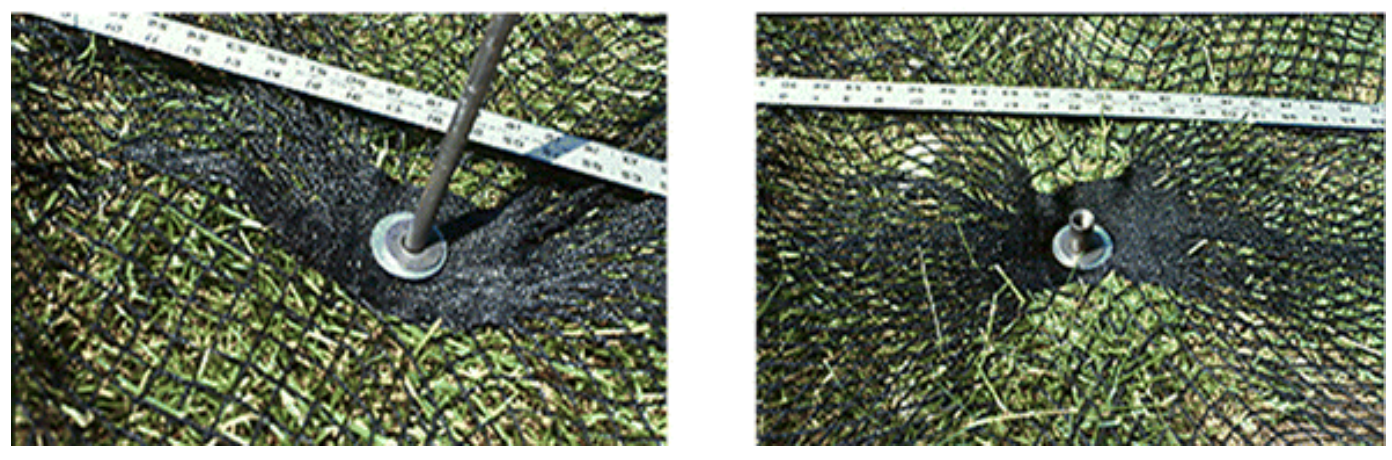

Non-synthetic materials, that may or may not be biodegradable, have also shown success in erosion control. Jute fibers of appropriate length and quantity can be used to improve soil properties when unconfined compressive strength and California bearing rate testing is performed (Ramkrishan et al. 2019). While the maximum intensity of the rainfall will ultimately affect performance, multiple biodegradable textile materials such as jute and wool have been shown to reduce soil loss by up to $98 \%$ even on slopes with 
60 degree or higher angles (Tauro et al. 2018). Many biodegradable fibers can be used not only as a soil admixture but also in textile mats. Specifically, jute geotextile mats (JGT) have shown success as an erosion deterrent in that, as it degrades, nutrients are added to the soil (Choudhury et al. 2009).

Expanded polystyrene (EPS) blocks have been used in previous studies to provide economical slope stabilization. This lightweight fill material improves the interaction between existing slope materials to decrease erosive forces (Arellano et al. 2011). Typical EPS stabilization is illustrated in Figure 9. Research featuring the refinement of design has been found by the National Cooperative Highway Research Program (NCHRP) to increase the effectiveness of EPS block stabilization (Arellano et al. 2010).

Figure 9. Typical EPS block application (Arellano et al. 2011).
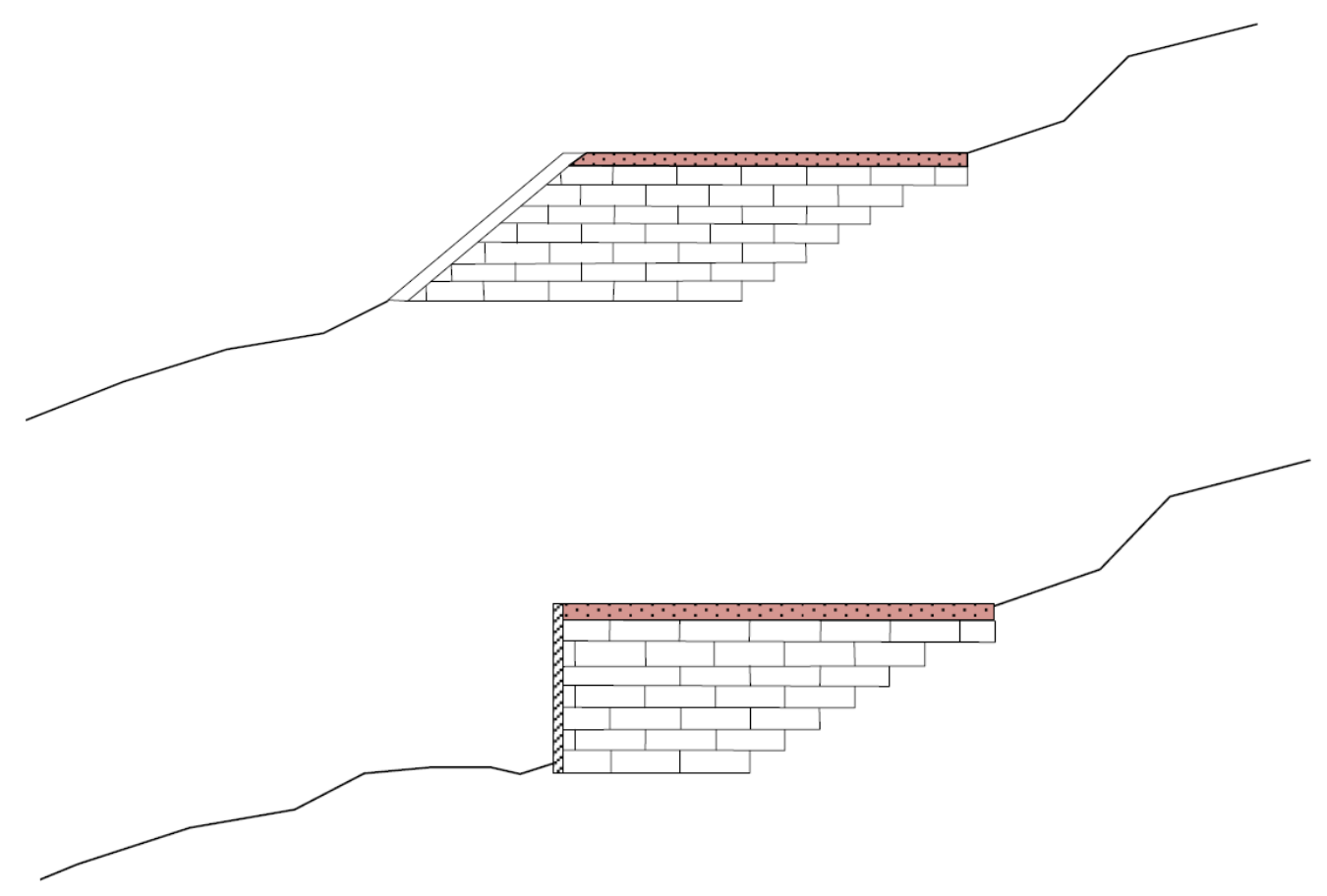

\subsection{Vegetation based stabilization}

Vegetation-based stabilization, sometimes also referred to as bioengineering, is the method of reinforcing a slope or applying erosion control by introducing organic plant matter, seeding, or a combination thereof.

Vegetation-based methods are often less costly than techniques such as anchoring, geosynthetics, and shotcrete. Soil bioengineering is generally 
seen as a sustainable, environmentally friendly process, especially if the organic material is already native to the area.

Changes in the soil itself may include moisture adjustments necessary to support organic material and an increase in deleterious materials. Organic plant matter can change the direction of moisture flow as the vegetation draws moisture from the soil, reducing the effect or likelihood of participation-based erosion. Vegetation roots are also able to increase the shear strength of the soil (Gray and Sotir 1996, Wu et al. 1979, Khan and Lateh 2015). With correct implementation, these resisting forces can be applied to reduce shallow shear failure as well as soil surface erosion (Koerner 2015).

Vegetation for bioengineering can be local to promote sustainability or individually tailored to provide the maximum erosion control. Long rooted, sturdy vegetation that is also quick growing, such as vetiver grass, has been shown to significantly increase shear strength and slope stability. Vetiver grass and its impact on slope stability in centrifuge testing is shown in Figure 10 and Table 2. This particular grass shows rapid root growth within one year.

Figure 10. Vetiver grass sample (Koerner 2015).

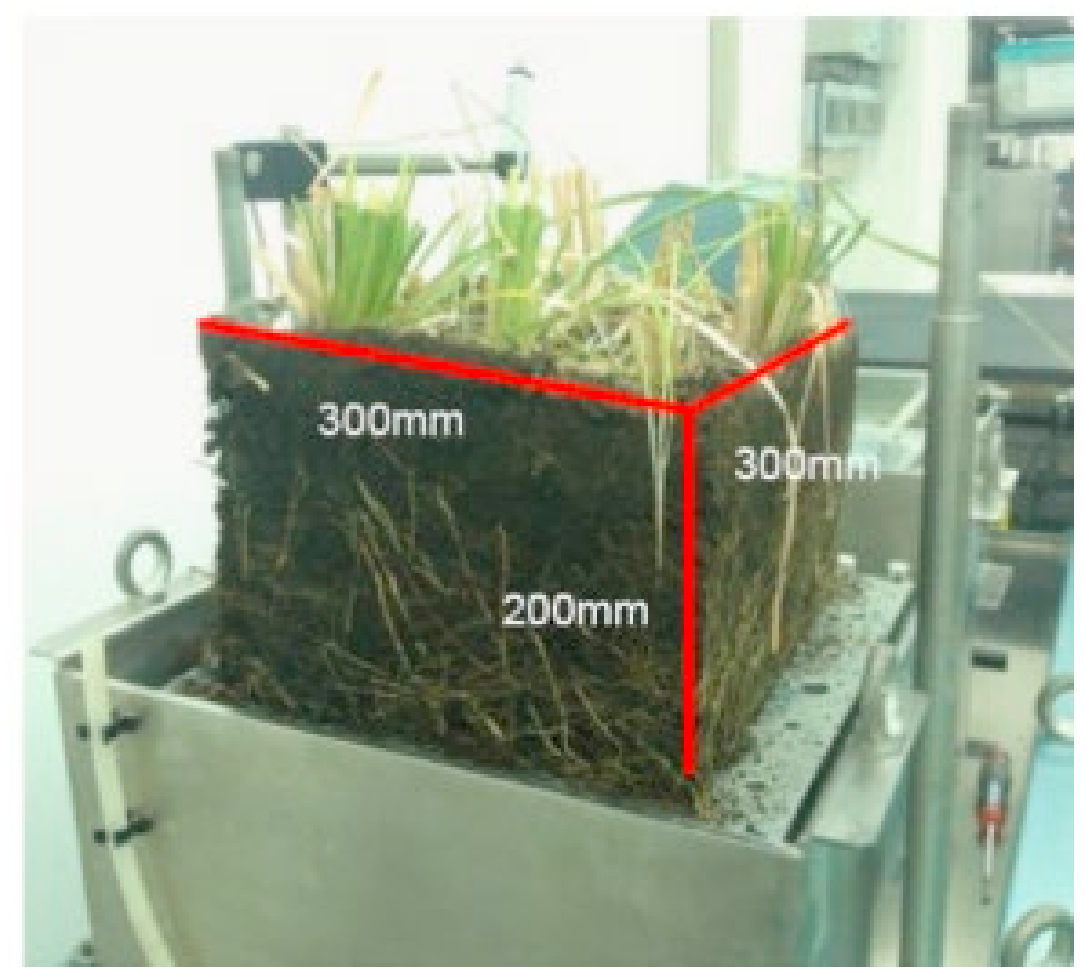


Table 2. Vetiver grass centrifuge testing results .

\begin{tabular}{|l|l|l|c|l|}
\hline Tests & Model case & Real case & $\begin{array}{l}\text { Displacement } \\
(\mathrm{mm})\end{array}$ & $\begin{array}{l}\text { Slope } \\
\text { deformation }\end{array}$ \\
\hline 1 & Unreinforced & Bare soil & 16 & Collapsed \\
\hline 2 & $\begin{array}{l}\text { Fishing line with } \\
20-\text { mm-deep } \\
\text { reinforced zone }\end{array}$ & $\begin{array}{l}\text { 1-m-deep vetiver } \\
\text { grass (4 months old) }\end{array}$ & 8 & $\begin{array}{l}\text { Collapsed; } \\
\text { fewer cracks } \\
\text { on surface }\end{array}$ \\
\hline
\end{tabular}

Recent advances in soil bioengineering included additional formulations and data collection in an attempt to clarify the feasibility of slope stability bioengineering projects. For example, in some scenarios, vetiver grass may be more beneficial to slope stabilization, but in scenarios with significantly different soil properties, Bermuda grass may be optimal (Noorasyikin and Zainab 2015, Noorasyikin and Zainab 2018). If possible, it is generally perceived as environmentally responsible to choose indigenous species to stabilize slopes. With the appropriate implementation process, the indigenous species may prove to be as efficient as introduced vegetation (Ranjan et al. 2015).

Similar to soil nailing or piles, vegetation "poles" can be utilized to add initial stability while promoting increased vegetation growth. These poles provide lateral resistance to soil movement at the slip surface. Figure 11 shows design methodology and installation for a slope undergoing live pole stabilization. 
Figure 11. Live pole stabilization (Wu et al. 2008).

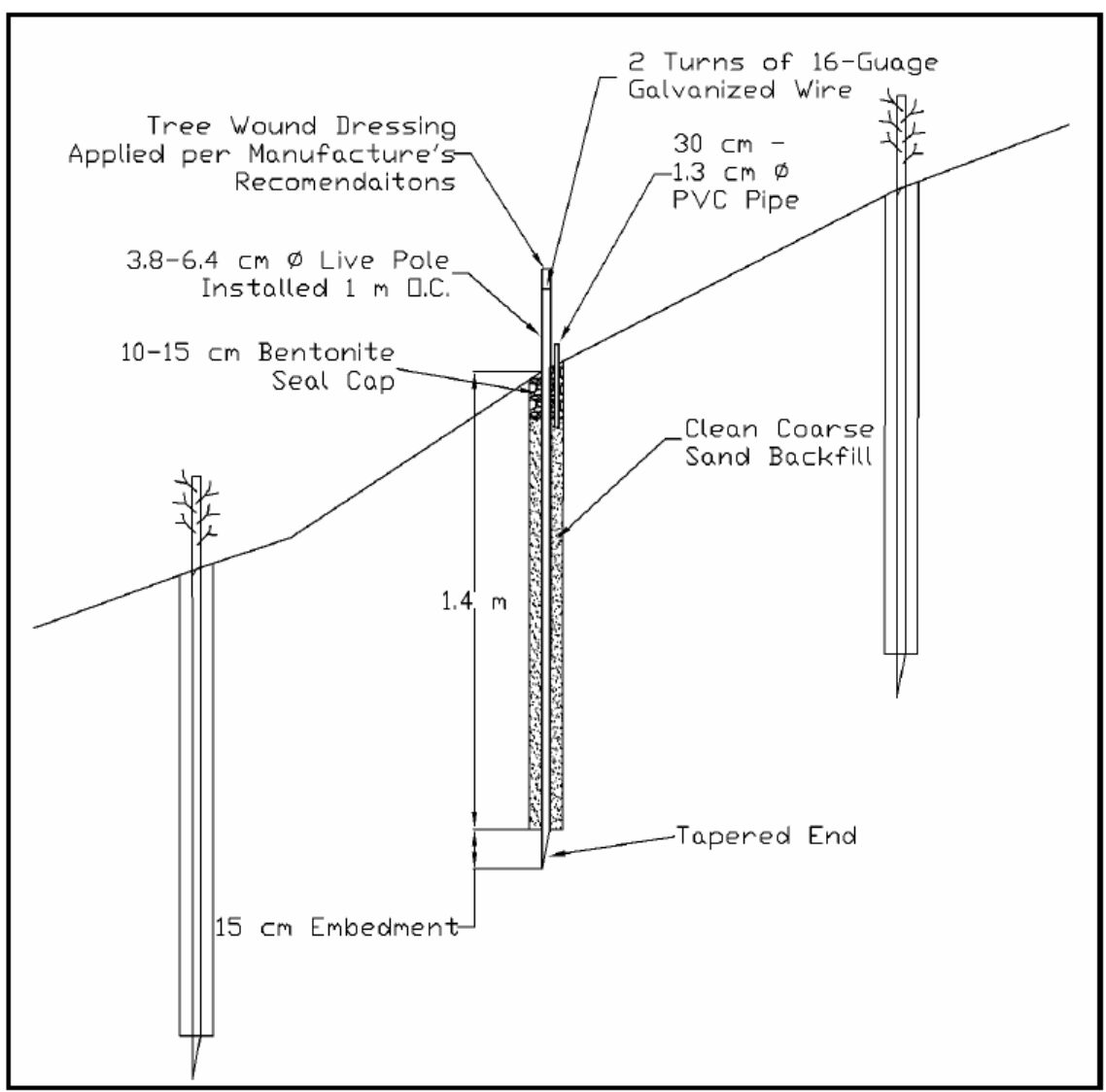

Procedures and methods have been conducted to evaluate and identify appropriate candidate sites for vegetation stabilization efforts. A team of environmental experts and civil engineers concluded that rain intensity, seepage, slope angle, drainage condition, and ground layer were the crucial data points in determining the feasibility of vegetation efforts (Kil et al. 2016). Therefore, based on local weather patterns and soil available, it should be possible to quickly identify if vegetation stabilization would be an effective method to control soil embankment erosion.

Seeding of slopes can be extremely time and cost efficient if immediate stabilization is not required. Recent studies have shown success in seeding areas affected by wildfires to reestablish vegetation prior to slope erosion (Peterson et al. 2008). Seeding using a germination blanket can allow for simple distribution of seeds while providing some layer of protection until the germination blanket degrades (Richardson et al. 2005). 
Hydroseeding is an advanced seeding technique in which seeds, water, and, in some cases, fertilizers are combined and applied in a spraying operation. This application allows for dense and rapid vegetation growth to protect the slope from erosion (Parsakhoo et al. 2018). Like other types of vegetative stabilization, the exact combination of seed, water, and fertilizers are tailored to each specific location and soil type to maximize erosion control.

Computational methodology to determine the appropriate vegetation type and likely success of an operation are widely available (Punetha et al. 2019, Switala and $\mathrm{Wu} 2013$ ). Individual tools to measure potential and final degree of success, such as the Index of Ecological Success (IES) and Ecological Index of Maturity (IEM), are available to ascertain the appropriate use and approximate benefits of various site scenarios (Giupponi et al. 2017). Overviews of various vegetation stabilization products and intended uses are also available (Georgi and Stathakopoulos 2016, Goldsmith et al. 2014, Nabeshima and You 2007). Installation techniques for these materials vary by vegetation type, but common techniques have been established and studied to provide guidance for utilization (Fox et al. 2010).

As in the other aforementioned stabilization techniques, there are possible combinations of vegetation and other materials, such as soil nailing with vegetation root systems that have been shown to be beneficial (Bo et al. 2015, Jotisankasa 2013). In a recent case study, the combination of soil nailing and vegetative roots was successfully used to stabilize a rocky slope (Galvao et al. 2010). The project was deemed to be cost effective and improved natural drainage.

\subsection{Chemical stabilization}

Lime-based stabilization is a fairly common technique to increase soil density and compressive strength of in-situ soils. Local soils are tested for basic properties and then mixed with specific lime dosage rates. The beneficial properties obtained from lime dosing is usually a result of several processes including an exchange of cations, agglomeration, pozzolanic reactions, and carbonation (Wu et al. 2017).

Soil cement is commonly used in roadway base layers but has shown successful use in erosion control (Wu et al. 2017). Like in roadway design, the soil is mixed with specified amounts of cement, water, and, in some cases, 
supplementary materials. The soil cement mixture is then placed on site and compacted to meet density requirements. Under correct application, the densified soil is better able to withstand erosive forces. Soil-cement application can be a cheaper alternative to other methodologies especially if the in-situ soil is utilized (Wu et al. 2017).

Both Portland cement and cement kiln dust have been shown to increase optimum moisture content and decrease maximum dry unit weight. In a case study of a slope in Socorro, New Mexico, the soil loss after treatment was decreased significantly under normal rainfall (Farid et al. 2011).

Combinations of materials may be derived for a specific soil to optimize desired properties. For example, an admixture dose consisting of compost, lime, and polypropylene fiber has been shown to mitigate desiccation cracking and surficial failure in high-plasticity clays on a dam maintained by the Corps of Engineers (Dronamraju 2008). Non-traditional chemical additives, namely non-cementitious-based materials, have emerged as a potential soil stabilization product. However, long term effects of these chemical additives on soil properties are still unclear (Tingle et al. 2007). 


\section{Evaluation of Methodologies}

Some additional concerns are likely present with the majority of these erosion control strategies. Some soils such as expansive clays can prove to be especially difficult to stabilize and should be avoided (Petry and Armstrong 1989). Carbon Dioxide $\left(\mathrm{CO}_{2}\right)$ and other greenhouse gases have a potential to be byproducts of certain soil stabilization techniques. Current environmental practices, such as the Global Warming Potential (GWP) index, may be required to understand how a substantial amount of particular soil stabilization techniques may affect the local and global environments (Gross et al. 2018).

In general, slope stability analysis can be conducted using a variety of modeling techniques to determine the potential for erosion or soil movement (Usluogullari et al. 2016, Zhang et al. 2016, Chearnkiatpradab 2005). Case studies on specific slope failures that included the effect of water are also readily available (Bates et al. 2006). Attempts to establish engineering guidelines as to the optimal stabilization technique for a given slope scenario have been conducted, and various treatment methods are ranked by perceived appropriateness (Puppala et al. 2013).

\subsection{Optimum methodologies for use in ECMs}

Traditional mechanical stabilization techniques are likely the most commonly used strategies for erosion control. However, for this specific application, any technique that requires concrete or steel could potentially be seen as a debris hazard. This includes commonly designed concrete retaining walls, coverings, columns, and grouting as well as concrete and steel anchoring techniques, such as soil nailing. Less common materials such as bamboo and RPPs may alleviate some debris hazard concerns. Mechanical stabilization utilizing only compaction would negate debris concerns but is generally less effective than other methods.

Fibrous non-hard materials such as synthetic and non-synthetic geogrids, geomats, textiles, and foams can provide some level of erosion protection while still achieving a low level of potential debris. These materials would likely cause no more damage as debris than soil cover, but are generally more expensive than other methods and must be tailored to specific soil types and properties. 
Vegetation-based stabilization can provide low cost, highly effective erosion control. However, the specific vegetation design and effectiveness are based heavily on local soil type, and the vegetation-based stabilization is not possible in all scenarios. With some vegetation types, initial germination times must be achieved before erosion control is effective. In most applications, vegetation-based stabilization will create no additional debris concern.

Chemical stabilization, specifically through the addition of cementitious materials, can allow the soil to achieve design erosion control properties while not adding any additional debris. With proper application, the soil can be brought to density and strength requirements that will alleviate erosion but allow the soil to break apart in the event of detonation. This method is common in roadway-base layers and is generally seen as lowcost and low-construction effort.

Table 3 illustrates some of the potential strengths and weaknesses of multiple methods. Debris potential, cost, and constructability were estimated based on a sliding scale of most optimal (scored 3) to most pessimal (scored 1) considering the categories listed. For example, row 1 (Mechanical Concrete column/grout/facing/piles/nails) is perceived as having a lower than average score on debris potential, cost, and constructability compared to the other methods available. This assumes that all methods are able to provide the desired level of erosion control, which should be possible when tailored to specific ECM environments.

Table 3. Comparison of methodologies.

\begin{tabular}{|l|l|c|c|c|}
\hline \multicolumn{1}{|c|}{ Type } & \multicolumn{1}{|c|}{ Material/Application } & $\begin{array}{c}\text { Debris } \\
\text { Potential }\end{array}$ & Cost & Constructability \\
\hline Mechanical & Concrete column/grout/facing/nails & 1 & 1 & 1 \\
\hline Mechanical & Steel piles/nails & 1 & 1 & 1 \\
\hline Mechanical & Alternative materials piles/nails & 1 & 1 & 1 \\
\hline Mechanical & Mats/grids/fibers & 3 & Varies & 2 \\
\hline Vegetation & Vegetation organic material & 3 & 3 & 2 \\
\hline Chemical & Cementitious-based material & 3 & 3 & 3 \\
\hline
\end{tabular}

*Scale of 1 to 3 in which 3 is most preferred and 1 is least preferred based on perceived averages of named methods. 


\section{Conclusions and Recommendations}

\subsection{Conclusions}

Based on the reviewed literature, it appears that chemical or vegetative stabilization are likely the best methods for ECM erosion prevention. This assumes that simple soil compaction is not adequate, as it is otherwise generally the best approach. Mechanical stabilization featuring fibrous materials is an alternative choice considering it would also add little to no debris potential.

Other aspects of ECM design, such as the limit on large-sized (cobble) aggregates to specific locations, were not found in any of the literature. Since background information on the basis of this limitation was not available, it is not possible to determine its appropriateness in modern ECM erosion control.

\subsection{Recommendations for additional study}

After a selection is made of a proposed solution to this issue, additional testing is suggested as a proof of erosion deterrence. Although the methods mentioned in this report all had prior use, it is recommended that the specific application be testing and monitored prior to widespread use. A test demonstration site featuring particularly harsh erosion conditions could be designated, and a small number of ECMs observed using the stabilization of choice with evaluation of soil retention. 


\section{References}

Air Force. June 2012 (rev). Air Force Manual (AFMAN) 91-201, Safety Programs, Explosives Safety Standards and Air Force Munitions Facilities Guide. http://www.wbdg.org/FFC/AF/AFMAN/afman91-201.pdf

Alfaro, M.C., J.A. Blatz, W.F. Abdulrazaq, and C. Kim. 2009. Evaluating shear mobilization in rockfill columns used for riverbank stabilization. Canadian Geotechnical Journal Vol. 46, Iss. 8, pp. 976-986. doi:10.1139/To9-036.

Arellano, D., J. Tatum, T. Stark, J. Horvath, and D. Leshchinsky. 2010. Framework for design guideline for expanded polystyrene block geofoam in slope stabilization and repair. Transportation Research Record: Journal of the Transportation Research Board 2170, 100-108. doi:10.3141/2170-12.

Arellano, D., T.D. Stark, J.S. Horvath, D. Leshchinsky, M.H. Kafash, and C. Wang. 2011. Overview of NCHRP design guideline for EPS-block geofoam in slope stabilization and repair. Paper presented at the 4th International Conference on Geofoam Blocks in Construction Application. Lillestrøm, Norway: EPS 2011.

Army, U. S. 2011. Army regulation (AR) 385-10: The Army safety program. Washington, DC: Department of the Army.

Bates, E., R. St. Louis, S. Douglas, and R. Sheets. 2006. Slope monitoring and failure mitigation techniques applied in the gold quarry open pit. Golden, Colorado: American Rock Mechanics Association.

Beck, W. Ken and Lok M.Sharma. 2013. "Mississippi River Road Gabion Wall/Slope Stabilization." $7^{\text {th }}$ International Conference on CaseHistories in Geotechnical Engineering. 61. https://scholarsmine.mst.edu/icchge/7icchge/sessiono3/61

Bhuiyan, M.R.H. 2014. Group resistance of recycled plastic pin in sustainable slope stabilization. Dissertation. University of Texas, Arlington.

Bo, M. W., M. Fabius, A. Arulrajah, and S. Horpibulsuk. 2015. In Indraratna B., Chu J. and Rujikiatkamjorn C.(Eds.), Chapter 21 - environmentally friendly slope stabilization using a soil nail and root system in Canada ButterworthHeinemann. doi://doi.org/10.1016/B978-0-08-100191-2.00021.

Boeckmann, A.Z. 2006. Load transfer in micropiles for slope stabilization from tests of large-scale physical models. Thesis. University of Missouri, Columbia.

Castro, D., and L. Lopez. 2006. Using disused rails for slope stabilization. Paper presented at the 5th Iceg - Environmental Geotechnics - Opportunities, Challenges and Responsibilities for Environmental Geotechnics, pp. 1297-1304.

Chearnkiatpradab, B. 2005. Expert system for slope stabilization. Geotechnical engineering for disaster mitigation and rehabilitation. World Scientific, pp. 335340. doi:10.1142/9789812701602_0033. 
Chen C.W., Hani, S., J.J. Bowders, L.J. Erik, and O. Jacob. 2017. Creep behavior of recycled plastic lumber in slope stabilization applications. Journal of Materials in Civil Engineering Vol. 19, Iss. 2, pp. 130-138.

Chen, G.Z., and J.Q. Jia. 2008. Case study of slope stabilization using compression anchor and reinforced concrete beam. Paper presented at the Proceedings of the International Young Scholars Symposium on Rock Mechanics, pp. 455-458.

Chen, H., and S.H. Liu. 2007. Slope failure characteristics and stabilization methods. Canadian Geotechnical Journal Vol. 44, Iss, 4, pp. 377-391.

Choudhury, P.K., A. Das, D.N. Goswami, and T. Sanyal. 2009. T. Bio-engineering approach with jute geotextile for slope stabilization. Paper presented at the Geosynthetics in Civil and Environmental Engineering, pp. 863-867.

Collins, R., M. Zhang, X. Zhang, L. Hulsey, T. Ravens, and R. Van Veldhuizen. 2015. Evaluation of geofibers and nontraditional liquid additives on erodible slopes in interior Alaska. Geotextiles and Geomembranes Vol. 43, Iss. 5, pp 412-423.

DA PAM. 1997. Ammunition and Explosives Safety Standards DA PAM 385-64. Washington, DC: Headquarters, Department of the Army.

Department of Defense Explosives Safety Board (DDESB). June 2004. Approved Protective Construction. Technical Paper 15A. Alexandria, VA: DDESB.

DDESB. March 2008. DoD Contractors' Safety Manual for Ammunition and Explosives. DoD 4145.26-M. Alexandria, VA: DDESB.

DDESB. March 2012 (Rev.). DoD Ammunition and Explosives Safety Standards: General Explosives Safety Information and Requirements. DoD 6055.09-M. Alexandria, VA: DDESB. https://www.wbdg.org/ffc/dod/manuals/dod-605509-m-volume-1

Dronamraju, V. S. 2008. Studies on field stabilization methods to prevent surficial slope failures of earth fill dams. Dissertation. University of Texas, Arlington.

Eab, K.H., S. Likitlersuang, and A. Takahashi. 2015. Laboratory and modelling investigation of root-reinforced system for slope stabilization. Soils and Foundations Vol. 55, Iss. 5, pp. 1270-1281. October 2015.

Farid, S., R. Mehrdad, C. Kolleen, and G. Bahareh. 2011. Stabilization of soils with Portland cement and CKD and application of CKD on slope erosion control. ASCE Geofrontiers Conference Vol. 397, Iss. 80.

Fox, Patrick J., T.H. Wu, and Brian Trenner. 2010. Bio-engineering for land stabilization. State Job Number 134169. Columbus, OH: Ohio Department of Transportation, Office of Research and Development.

Galvão Terezinha Cássia, B., A.R. Pereira, M.G. Parizzi, and S.H. Alvesda. 2010. Bioengineering techniques associated with soil nailing applied to slope stabilization and erosion control. Natural Hazards Review Vol. 11, Iss. 2, pp. 4348. 
Georgi, J., and I. Stathakopoulos. 2006. Bioengineering techniques for soil erosion protection and slope stabilization. 46th Congress of the European Regional Science Association: "Enlargement, Southern Europe and the Mediterranean", August 30 - September 3, 2006, Volos, Greece.

Giupponi, L., G.B. Bischetti, and A. Giorgi. 2017. A proposal for assessing the success of soil bioengineering work by analyzing vegetation: Results of two case studies in the Italian Alps. Landscape and Ecological Engineering Vol. 13, Iss. 2, 2017.

Goldsmith, W., D. Gray, and J. McCullah (Eds.). 2014 Bioengineering case studies: Sustainable stream bank and slope stabilization. New York, NY: Springer New York. doi:10.1007/978-1-4614-7996-3_23.

Gray, D.H., and R.B. Sotir. 1996. Biotechnical and Soil Bioengineering Slope Stabilization: A Practical Guide for Erosion Control. New York: John Wiley \& Sons.

Gross D., S. Kytzia, and A. Roduner. 2018. Comparison of the CO2 Record of Different Slope Stabilization Methods. In: Frikha W., Varaksin S., Viana da Fonseca A. (eds) Soil Testing, Soil Stability and Ground Improvement. GeoMEast 2017. Sustainable Civil Infrastructures.

Haghshenas, S.S., R. Mikaeil, S.S. Haghshenas, M.Z. Naghadehi, and P.S. Moghadam. 2017. Fuzzy and classical MCDM techniques to rank the slope stabilization methods in a rock-fill reservoir dam. Civil Engineering Journal Vol. 3, Iss. 6, pp. 382-394.

Hajiazizi, M., and A.R. Mazaheri. 2015. Use of line segments slip surface for optimized design of piles in stabilization of the earth slopes. International Journal of Civil Engineering Vol. 13, Iss. 1, pp. 14-27.

Hussain, S. 2017. Study of Lime Column as a Ground Improvement Technique in Soft Soil. Thesis. NUST Institute of Civil Engineering.

Ismail, M.A.M., S.M. Ng, M.H.Z. Abidin, and A. Madun. 2018. Subsurface characterization using geophysical seismic refraction survey for slope stabilization design with soil nailing. Journal of Physics: Conference Series Vol. 995, Iss. 1.

Jotisankasa, A. 2013. Application of local plant species for live stake as a bio-slope stabilization method in Thailand. Paper presented at the Tokyo Tech-KU Joint Seminar on Infrastructure Development, pp. 145-150.

Jotisankasa, A., and N. Rurgchaisri. 2018. Shear strength of interfaces between unsaturated soils and composite geotextile with polyester yarn reinforcement. Geotextiles and Geomembranes Vol. 46, Iss. 3, pp. 338-353.

Khan M.S., M.S. Hossain, M.A. Khan, M. Faysal. 2017. Performance of Recycled Plastic Pin (RPP) for Slope Stabilization. In: Frikha W., Varaksin S., Viana da Fonseca A. (eds.) Soil Testing, Soil Stability and Ground Improvement. GeoMEast 2017. 
Khan, M., M.D. Hossain, A. Ahmed, and M. Nobahar. 2018. Simplified design method of slope stabilization using recycled plastic pin. Paper presented at the Transportation Research Board 97th Annual Meeting. Retrieved from https://trid.trb.org/view/1495800.

Khan, M.S., H. Sahadat, and K. Golam. 2016. Slope stabilization using recycled plastic pins. Journal of Performance of Constructed Facilities Vol. 30, Iss. 3.

Khan, Y. A., and H. Lateh. 2015. Plant root reinforcement against local failure mechanism of natural slope. Paper presented at the Engineering Geology for Society and Territory - Vol. 2, pp. 1275-1280.

Kil, S., D. Lee, J. Kim, M. Li, G. Newman, S. Kil, and G. Newman. 2016. Utilizing the analytic hierarchy process to establish weighted values for evaluating the stability of slope revegetation based on hydroseeding applications in South Korea. Sustainability Vol. 8, Iss. 1, pp. 58.

Koerner, R.M. 2015. In-Situ Stabilization of Soil Slopes Using Nailed or Anchored Geosynthetics. Int. J. of Geosynth. and Ground Eng. 1: 2. Springer International Publishing. https://doi.org/10.1007/s40891-014-0002-2.

Kumar, N., and D. Das. 2018. Nonwoven geotextiles from nettle and poly (lactic acid) fibers for slope stabilization using bioengineering approach. Geotextiles and Geomembranes Vol. 46, Iss. 2, pp. 206-213.

Li, J., L.G. Tham, S.M. Junaideen, Z.Q. Yue, and C.F. Lee. 2008. Loose fill slope stabilization with soil nails: Full-scale test. Journal of Geotechnical and Geoenvironmental Engineering Vol. 134, Iss. 3, pp. 277-288, 2008.

Li, J., Y. Tang, and X. Zhu. 2011. Research of a new bioengineering technique for highway slope protection. International Conference on Remote Sensing, Environment and Transportation Engineering 2011.

Li, L., and R.Y. Liang. 2014. Limit equilibrium based design approach for slope stabilization using multiple rows of drilled shafts. Computers and Geotechnics Vol. 59, Iss. 6, pp. 67-74.

Li, X., X. Pei, M. Gutierrez, and S. He. 2012. Optimal location of piles in slope stabilization by limit analysis. Acta Geotechnica Vol. 7, Iss. 3, pp. 253-259.

Mahmood, M., N. Tung, G. Matthew, and P. Tim. 2014. Mountain lake embankment slope stabilization by vertical vibrated stone columns, Highway 1, San Francisco Bay area. International Conference on Sustainable Infrastructure.

McCormick, W. 2014. Slope stabilization with platepiles. Civil + Structural Engineer Magazine. January edition. https://www.csengineermag.com/article/slope-stabilizationwith-platepiles

Monsberger, C., W. Lienhart, S. Hirschmüller, and R. Marte. 2018. Monitoring of soil nailed slope stabilizations using distributed fiber optic sensing. Sensors and Smart Structures Technologies for Civil, Mechanical, and Aerospace Systems Vol.10598. 
Nabeshima, Y., and S. You. 2007b. Structural-mechanical stabilized slopes/walls with vegetation and planting works. Korean Geosynthetics Society, Vol. 6, Iss. 4, pp.36-50.

NAVSEA Manual OP 5 Volume 1, Ammunition and Explosives Safety Ashore. Washington, DC: U.S. Government Printing Office.

Noorasyikin, M.N., and M. Zainab. 2018. The potential of unknown microorganisms on growth of vetiver grass and bermuda grass and nutrient uptake toward slope stabilization. Journal of Fundamental and Applied Sciences 10(5S).

Noorasyikin, M.N., and M.A. Zainab. 2015. A study on the effectiveness of Soil-Root matrix of Vetiver grass and Bermuda grass as soil slope reinforcing system. Paper presented at the International Civil and Infrastructure Engineering Conference. InCIEC Proceedings pp. 331-342. DOI: 10.1007/978-981-10-0155-0.

Parsakhoo, A., M. Jajouzadeh, and A.R. Motlagh. 2018. Effect of hydroseeding on grass yield and water use efficiency on forest road artificial soil slopes. Journal of Forest Science Vol. 64, Iss. 4, pp. 157-163.

Peterson, D., R. Harrod, T. Lillybridge, and M. Bennett. 2008. Evaluating the efficacy and ecological impacts of bare slope stabilization treatments on the pot peak/deep harbor wildfire complex. JFSP Research Project Reports. Project Active ID:05-12-02.

Petry, T.M., and J.C. Armstrong. 1989. Stabilization of expansive clay soils. Transportation Research Record, 1219.

Pohll, G.M., R.W.H. Carroll, D.M. Reeves, R. Parashar, B.Muhunthan, S. Thiyagarjah, T. Badger, S. Lowell, and K.A. Willoughby. 2013. Design guidelines for horizontal drains used for slope stabilization. Report WA-RD 787.1. Federal Highway Administration.

Pun, W.K., and G. Urciuoli. 2008. Soil nailing and subsurface drainage for slope stabilization. Paper presented at the Proceedings of the Tenth International Symposium on Landslides and Engineered Slopes, pp. 85-126.

Punetha, P., M. Samanta, and S. Sarkar. 2019. Bioengineering as an effective and ecofriendly soil slope stabilization method: A review. In S. P. Pradhan, V. Vishal and T. N. Singh (Eds.), Landslides: Theory, practice and modelling, pp. 201-224. Cham: Springer International Publishing. doi:10.1007/978-3-319-77377-3_10.

Puppala, A.J., B.C.S. Chittoori, N. Talluri, and M. Le. 2013. Stabilizer selection for arresting surficial slope failures: A sustainability perspective. Geo-Congress.

Quansah, A., F.R. Kazadi, F.T. Mohammed, and A.M. Ali. 2018. Optimum design analysis of a nailed slope based on limit equilibrium methods: Case study - cluj-napoca landslide. Journal of Civil Engineering Research Vol. 8 Iss. 3, pp. 49-61.

Rahardjo, H., V.A. Santoso, E.C. Leong, Y.S. Ng, C.P.H. Tam, and A. Satyanaga. 2013. Use of recycled crushed concrete and secudrain in capillary barriers for slope stabilization. Canadian Geotechnical Journal Vol. 50, Iss. 6, pp. 662-673. 
Ramkrishnan, R., V. Karthik, M.R. Sruthy, and A. Sharma. 2019. Soil reinforcement and slope stabilization using natural jute fibres. Paper presented at the New Solutions for Challenges in Applications of New Materials and Geotechnical Issues, pp. 130-143.

Ranjan, V., P. Sen, D. Kumar, and A. Sarsawat. 2015. A review on dump slope stabilization by revegetation with reference to indigenous plant. Ecological Processes Vol. 4, Iss. 1, pp. 14.

Richardson, M., T.C. Daniel, and J.H. McCalla. 2005. Slope stabilization using a turf grass germination blanket. Paper presented at the ASA-CSSA-SSSA International Annual Meetings, November 6-10.

Selvakumar, S., and B. Soundara. 2019. Expanded polystyrene (EPS) geofoam columns in expansive soil: Preliminary swelling characteristics evaluation. Paper presented at the 5th International Conference on Geofoam Blocks in Construction Applications, pp. 331-338.

Sharma, A., P.T. Raju, V. Sreedhar, and H. Mahiyar, H. 2019a. Slope stability analysis of steep, reinforced soil slopes using finite element method. Paper presented at the Geotechnical Applications, pp. 163-171.

Sharma, M., M. Samanta, and S. Sarkar. 2019b. Soil nailing: An effective slope stabilization technique. In S. P. Pradhan, V. Vishal \& T. N. Singh (Eds.), Landslides: Theory, practice and modelling (pp. 173-199). Cham: Springer International Publishing. doi:10.1007/978-3-319-77377-3_9

Shukla, S., N. Sivakugan, and B. Das. 2011. A state-of-the-art review of geosyntheticreinforced slopes. International Journal of Geotechnical Engineering Vol. 5, Iss. 1, pp. 17-32.

Smith, J., C. Grapel, S. Proskin, and S. Oad. 2009. Use of launched soil nails to stabilize shallow slope failure on urban access road 172. Paper presented at the 2009 Annual Conference and Exhibition of the Transportation Association of Canada Transportation in a Climate of Change.

Switala, B.M., and W. Wu. 2013. Analysis of slope stabilization by soil bioengineering method. Paper presented at the EGU General Assembly 2013, Vienna, Austria.

Tardio, G., S.B. Mickovski, H.P. Rauch, J. Acharya, and M. Sudan. 2018. The use of bamboo for erosion control and slope stabilization: Soil bioengineering works. Bamboo - current and future prospects (pp. 105-122). IntechOpen. doi:10.5772/intechopen.75626.

Tauro, F., P. Cornelini, S. Grimaldi and A. Petroselli. 2018. Field studies on the soil loss reduction effectiveness of three biodegradable geotextiles. Journal of Agricultural Engineering pp. 117-123. doi:10.4081/jae.2018.799.

Thelen, M., and D. Thome. 2013. M-222 slope stabilization case history - geotechnical lessons learned from Michigan Department of Transportation design build project. Paper presented at the International Conference on Case Histories in Geotechnical Engineering 60. 
Tingle, J.S., J.K. Newman, S.L. Larson, C.A. Weiss, and J.F. Rushing. 2007. Stabilization mechanisms of nontraditional additives. Transportation Research Record J. Transp. Res. Board, pp. 59-67. No. 1989.

Turnbull, W. 2017. Geosynthetically confined soil walls for roadway reclamation. Paper presented at the 68th Highway Geology Symposium (HGS 2017), Retrieved from https://trid.trb.org/view/1474082.

Unified Facilities Criteria (UFC). May 2015. Ammunition and Explosives Storage Magazines. UFC 4-420-01. https://www.wbdg.org/FFC/DOD/UFC/ufc_4_420_01_2015.pdf

Usluogullari, O.F., A. Temugan, and E.S. Duman. 2016. Comparison of slope stabilization methods by three-dimensional finite element analysis. Natural Hazards, Vol. 81, Iss. 2, pp. 1027-1050. doi:10.1007/s11069-015-2118-7.

Whole Building Design Guide. National Institute of Building Design: Washington, DC. Website: http://www.wbdg.org/design/ammo_magazines.php

Wu, J.Y., H. Kaiming, and S. Munira. 2017. Remediation of slope failure by compacted soil-cement fill. Journal of Performance of Constructed Facilities Vol. 31, Iss. 4. doi:10.1061/(ASCE)CF.1943-5509.0000998.

Wu, Tien H., Brian R. Trenner, Patrick J. Fox, Christopher M. Kokesh, Kirk Beach, and David H. Barker. "Soil-bioengineering for slope stabilization in Ohio." In GeoCongress 2008: Geosustainability and Geohazard Mitigation, pp. 883-890. doi:10.1061/40971(310)110.

Wu, T.H., W.P. McKinnell, and D.N. Swanston. 1979. Strength of tree roots and landslides on Prince of Wales Island, Alaska. Can. Geotech. J. 16, pp. 19-33.

Zhang, A., H. Mo, and J. Zhang. 2016. Analytical prediction for piles used for slope stabilization. Soil Mechanics and Foundation Engineering Vol. 53, Iss. 2, pp. 108-118. doi:10.1007/s11204-016-9373-9. 


\section{Appendix A: Additional Reference Material}

Table A1. Reference guide.

\begin{tabular}{|l|l|l|}
\hline Stabilization Type & Materials / Technique & References \\
\hline Mechanical & Columns, piles, soil nailing & $8-32$ \\
\hline Mechanical & Geogrids, mats, fibers & $40-51$ \\
\hline Vegetation & Vegetative material & $52-72$ \\
\hline Chemical & Cementitious material & $73-76$ \\
\hline
\end{tabular}




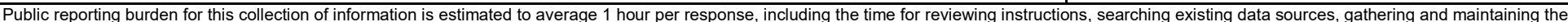

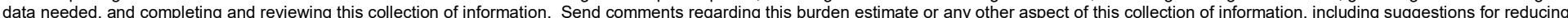

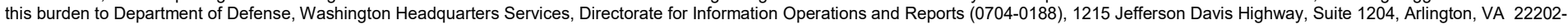

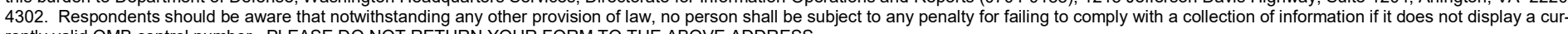
rently valid OMB control number. PLEASE DO NOT RETURN YOUR FORM TO THE ABOVE ADDRESS.

\section{REPORT DATE (DD-MM-YYYY) September 2019}

\section{TITLE AND SUBTITLE}

Erosion Control of Earth Covered Magazines to Maintain Minimum Cover Requirements

\section{DATES COVERED (From - To)}

\section{5a. CONTRACT NUMBER}

5b. GRANT NUMBER

5c. PROGRAM ELEMENT NUMBER

5d. PROJECT NUMBER

479377

5e. TASK NUMBER

5f. WORK UNIT NUMBER

8. PERFORMING ORGANIZATION REPORT NUMBER

ERDC/GSL TR-19-44

10. SPONSOR/MONITOR'S ACRONYM(S)

11. SPONSOR/MONITOR'S REPORT NUMBER(S)

Huntsville, AL 35816-5319

\section{U.S. Army Engineering and Support Center, \\ 9. SPONSORING / MONITORING AGENCY NAME(S) AND ADDRESS(ES) \\ U.S. Army Engineer Research and Development Center \\ Geotechnical and Structures Laboratory \\ Vicksburg, MS 39180-6199}

(2)

(1)

(1)

\section{DISTRIBUTION / AVAILABILITY STATEMENT}

Approved for public release; distribution is unlimited.

\section{SUPPLEMENTARY NOTES}

Org Code A0L0201, cross charge labor code 347426.

\section{ABSTRACT}

Soil erosion of cover for earth covered magazine (ECM) storage presents a unique challenge to traditional embankment practices. Due to the strict guidelines on the necessary soil cover, as well as material allowed for use in erosion deterrence, many traditional soil erosion techniques are not allowable. This report investigates current soil erosion techniques and their applicability to magazine cover focusing on regulations, costs, and ease of implementation. The techniques investigated were based on currently used techniques from 2003 to the present but did not include research-only stage mechanisms.

The objective of this research effort was to investigate currently available erosion mitigation methods and their feasibility for ECM application. Main areas of concern for ECMs are envisioned to be cost, ease of implementation, and potential for added debris.

Based on the reviewed literature, it appears that chemical or vegetative stabilization are likely the best methods for ECMs' erosion prevention. This assumes that simple soil compaction is not adequate, as it is otherwise generally the best approach. After a selection is made of a proposed solution to this issue, additional testing is suggested as a proof of erosion deterrence.

\section{SUBJECT TERMS}

Underground storage, Ammunition — Storage, Underground construction, Soil erosion, Soil conservation

\begin{tabular}{|c|c|c|c|c|c|}
\hline \multicolumn{3}{|c|}{ 16. SECURITY CLASSIFICATION OF: } & 17. LIMITATION & 18. NUMBER & 19a. NAME OF RESPONSIBLE PERSON \\
\hline $\begin{array}{l}\text { a. REPORT } \\
\text { Unclassified }\end{array}$ & $\begin{array}{l}\text { b. ABSTRACT } \\
\text { Unclassified }\end{array}$ & $\begin{array}{l}\text { c. THIS PAGE } \\
\text { Unclassified }\end{array}$ & SAR & 40 & $\begin{array}{l}\text { 19b. TELEPHONE NUMBER (in- } \\
\text { clude area code) }\end{array}$ \\
\hline
\end{tabular}

